\title{
Transnational Entrepreneurship: Distinctive Features and a New Definition
} Eduardo Bailetti

\author{
(6 Creating a structure for mutual prosperity requires") \\ lowering regional and transnational barriers to \\ facilitate the flow of goods and promote people-to- \\ people interactions.
}

Moon Jae-in

Current President of South Korea

\begin{abstract}
Definitions of transnational entrepreneurship are too general making it difficult to understand what distinguishes transnational entrepreneurship from other forms of entrepreneurship. In addition, these definitions identify the "immigrant", "ethnic", or "migrant" entrepreneur as the focal actor rather than the company. This makes it difficult to align transnational entrepreneurship with the theory of the firm and provide practical insights to practitioners. This article examines 11 definitions of transnational entrepreneurship, discovers the groups of words that best represent the information in a corpus comprised of 44 journal articles, identifies the key features that distinguish transnational entrepreneurship from other forms of entrepreneurship, and advances a new definition of transnational entrepreneurship. The results indicate that transnational entrepreneurship has two key distinctive features: cross-border investment logic and institutional distance - the difference in institutional context between countries. Accordingly, transnational entrepreneurship may be usefully defined as "a cross-border investment to acquire, combine, and recombine specialized individuals and heterogeneous assets to create and capture value for the company under conditions of institutional distance and uncertainty". This proposed definition builds on the features that make transnational entrepreneurship distinctive, is consistent with the theory of the firm, and carries implications for how to grow companies at an early stage.
\end{abstract}

\section{Introduction}

Insights into how and why a new entrepreneurial company can establish itself as a transnational company have not yet been provided by the developing field of transnational entrepreneurship. Given that new companies that grow their operations globally are worth more, grow quicker, and are more capable at adapting to uncertain environments (Bailetti \& Zijdemans, 2014), this is an important hurdle to overcome.

In this article, a review of the transnational entrepreneurship literature reveals three contributing factors that may be holding the field back from providing practical guidance on how to establish transnational business activities: i) varied and general definitions, ii) an absence of identified distinctive features, and iii) the presence of the entrepreneur rather than the firm as the focal actor.
Definitions of transnational entrepreneurship can be too general, and the perspectives used to define transnational entrepreneurship vary widely. This makes it difficult to understand what makes transnational entrepreneurship different from other fields. For example, transnational entrepreneurship is said to be about regular cross-border operations (Brzozowski et al., 2017). However, many operations that are carried out across borders have little to do with transnational companies (e.g., remittances, travel). Similarly, defining transnational entrepreneurship as the use of resources from two different fields to create competitive advantage (Patel \& Conklin, 2009) could apply to many scenarios, not just transnational entrepreneurship. It is hard to argue that an entrepreneur who uses resources from industry and academia - two different fields - to develop a new product is engaged in transnational entrepreneurship. 


\section{Transnational Entrepreneurship: Distinctive Features and a New Definition}

\section{Eduardo Bailetti}

In addition, it is observed that several definitions of transnational entrepreneurship identify the immigrant entrepreneur (Chen \& Tan, 2009; Sequeira et al., 2009; Brzozowski et al., 2014), the ethnic entrepreneur (Brzozowski, Cucculelli \& Surdej, 2017), or the migrant entrepreneur (Santamaria-Alvarez et al., 2018) as the focal actor rather than the company. Given that much of the attention on transnational entrepreneurship is from social science-related researchers (Drori et al., 2009), it is understandable that the individual entrepreneur is identified as the focal actor. However, the value the entrepreneur (and the team) creates and captures is embodied in the company, not the individual entrepreneur (Foss et al., 2011; Klein, 2016). Thus, wealth-creating entrepreneurial action is better understood when viewed from a perspective that is aligned with the theory of the firm and places the company as the focal actor.

Transnational entrepreneurship would therefore benefit from a new focused definition that highlights the field's distinctive features and is aligned with the theory of the firm. The new definition should contribute directly to practical insights that managers can employ.

Proposing a new definition can help update a field to recognize new developments, such as the case of Oviatt and McDougall's (2005) definition of international entrepreneurship, or it can leverage previous work in an emerging field to provide a clearer working definition, as in the case of Bailetti's (2012) definition of technology entrepreneurship. The author follows Bailetti's approach to proposing a definition of technology entrepreneurship (2012) in that it examines the literature's existing definitions to identify the distinctive features and proposes a new definition drawn upon them.

Thus, the objectives of this article are to identify what distinguishes transnational entrepreneurship from other forms of entrepreneurship and to offer a new definition that is useful to practitioners and researchers.

In the next section, a review of the definitions identified in the academic literature is presented and analyzed. Then, the results of using topic modelling to discover topics in a corpus comprised of journal articles are provided and discussed. The distinctive features of transnational entrepreneurship are identified using the results of these analyses, a new definition is proposed, and a comparison highlighting the advantages of the new definition is outlined. To conclude, the managerial implications for new companies are discussed, the contributions of the research are highlighted, and avenues for future research are suggested.

\section{A Review of Existing Definitions}

Table 1 provides 11 definitions of transnational entrepreneurship. The definitions were extracted from literature found using search terms "transnational entrepreneurship" and "transnational ventures". For inclusion, definitions required direct reference to transnational entrepreneurship followed by a direct definition or an explanation or description that resembled a definition. Definitions that described the transnational entrepreneur rather than the field were rejected. When a definition offered was a direct quotation from a prior article, the original source of the definition was used. The definition recorded for Patel and Conklin (2009) includes two separate passages where transnational entrepreneurship was defined: the first focused on transnational entrepreneurship as a process and the second focused on its outcome.

None of these definitions explicitly identify the company as the focal actor. Six of these definitions identify the immigrant, migrant, or ethnic entrepreneur as the focal actor (Brzozowski et al., 2014, 2017; Chen \& Tan, 2009; Lin, 2010; Santamaria-Alvarez et al., 2018; Sequeira, Carr \& Rasheed, 2009), three identify actors that are embedded in two or more social and economic arenas (Drori et al., 2009; Poblete, 2018; Prashantham et al., 2018), and three definitions do not identify the focal actor (Patel \& Conklin, 2009, p.1047 \& p.1050; Patel $\&$ Terjesen, 2011). Viewing transnational entrepreneurship from the perspective of the entrepreneur has great descriptive qualities but lacks prescriptive power for aspiring entrepreneurs seeking to grow new companies internationally. Without detailed discussion on what the company must do to achieve a transnational presence, there will be a shortage of practical managerial insights for future entrepreneurial action.

Table 1 suggests that transnational entrepreneurship has been defined using various perspectives, such as:

- To discover and enact cross-national opportunities (Chen \& Tan, 2009; Prashantham et al., 2018)

- As a process to establish social fields (Sequeira et al., 2009)

- As a process to adapt to change (Patel \& Conklin, 2009)

- To explain the use of resources and social networks (Lin, 2010; Patel \& Conklin, 2009; Patel \& Terjesen, 2011) 


\section{Transnational Entrepreneurship: Distinctive Features and a New Definition}

Eduardo Bailetti

Table 1. Definitions of transnational entrepreneurship in the literature

\begin{tabular}{lll}
\hline Definition $\quad$ Transnationalentrepreneurship... & Source \\
\hline $\begin{array}{l}\text { 1...is a multi-faceted process, in which immigrant entrepreneurs discover and } \\
\text { enact business opportunities across national borders. }\end{array}$ & Chen \& Tan (2009, p.1080) \\
\hline $\begin{array}{l}\text { f...epresents a form of economic transnationalism that immigrants engage in } \\
\text { for different purposes. }\end{array}$ & Sequeira et al. (2009, p.1026) \\
\hline $\begin{array}{l}\text {...is a process of economic adaptation based on mobilization of social } \\
\text { networks across borders... } \\
\text {...to leverage resources from two different social fields to create competitive } \\
\text { advantage. }\end{array}$ & Patel (2009, p.1047 \& p.1050) \\
\hline
\end{tabular}

4. ...involves entrepreneurial activities that are carried out in a cross-national context and initiated by actors who are embedded in at least two different

Drori et al. (2009, p.1001) social and economic arenas.

5. ...[occurs when] immigrants simultaneously engage in two or more socially $\quad$ Lin (2010, p.127) embedded environments and maximize their resource base by doing so.

6. ...is the ability to mobilize social networks in dual institutional settings.

Patel \& Terjesen (2011, p.64)

7. ...implies immigrant business engagement not only in the host country, but Brzozowski et al. (2014, p.551) also in the country of origin.

8. ...encompasses immigrant and (although on a smaller scale) ethnic entrepreneurs who maintain regular cross-border operations, marking their economic presence (at least) in two countries: the host and home economy.

Brzozowski et al. (2017, p.107)

9. ... [is] the process of transnational entrepreneurship involves entrepreneurial activities that are carried out in a cross-national context and initiated by actors who are embedded in at least two different social and economic arenas.

Poblete (2018, p.278) ... [is] the pursuit of entrepreneurial cross-national opportunities by actors embedded in different socio-economic arenas. business linkages with both the country of origin and the country of destination.

- For conducting business in a cross-national context (Brzozowski et al., 2014; Drori et al., Honig \& Wright, 2009; Poblete, 2018; Santamaria-Alvarez et al., 2018).

The author also examined the definitions in Table 1 by considering how the objects (focal actors, inputs, or outputs) are embedded in two or more settings (i.e., the surroundings where a phenomenon is positioned or where it takes place). This examination revealed that the definitions in this analysis can be grouped into three different viewpoints:
1. Where the individual is placed in the setting (Brzozowski et al., 2017; Drori et al., 2009; Lin, 2010; Patel \& Terjesen, 2011; Poblete, 2018; Prashantham et al., 2018; Santamaria-Alvarez et al., 2018)

2. Where the input is placed in the setting (Patel \& Conklin, 2009; Patel \& Terjesen, 2011)

3. Where the outcome is placed in the setting (Chen \& Tan, 2009; Sequeira et al., 2009) 


\section{Transnational Entrepreneurship: Distinctive Features and a New Definition}

\section{Eduardo Bailetti}

These findings demonstrate a lack of consensus within the field, which makes it difficult for focused, prescriptive insights to be provided to practitioners.

\section{Discovering Topics}

A corpus of recent, relevant, peer-reviewed journal articles related to transnational entrepreneurship was collected to discover the topics that best represent the field. The articles were selected along four criteria:

1. Search terms: "transnational entrepreneurship" and "transnational ventures"

2. Publication date: between January 1,2007 , and July 1 , 2018

3. Publishing journal's ranking: $A^{*}, A$, or $B$ according to the Master Journal List of the Australian Business Deans Council (updated April 30, 2018)

4. Relevance: the focus of the article must be on conducting business in two or more countries

The initial search resulted in 32 qualified articles. A brief search for additional articles which cite qualified articles produced an additional 12 articles. Appendix A lists the 44 articles used in the analysis.

To reveal the themes that exist within the 44 journal articles, the text of those articles was processed using a topic modelling visualization tool called the J-tool (jtool.cugcr.ca). Topic modelling is a machine learning method of analysis that enables the researcher to "analyze the words of the original texts to discover the themes that run through them" (Blei, 2012). Effectively, topic modelling clusters copious amounts of written material into related groups called "topics". All the articles within a topic share a common set of words, the meaning of which must be interpreted by the analyst who develops the topic model.

The J-tool uses an open-source statistical package called MALLET (mallet.cs.umass.edu/about.php), which is based on the Latent Dirichlet Allocation (LDA) topic modelling algorithm. For a high-level description of LDA and topic modelling please see Blei (2012), and for a deeper discussion of probabilistic modelling, refer to Blei and colleagues (2003) and Blei and Lafferty (2009).

To determine the appropriate number of topics to use for the topic model, the results of multiple topic models were compared, and the one interpreted as having the best "fit" was chosen for analysis. To determine fit, the author used a combination of parameters such as the level of data loss resulting from the topic model, the way the articles distributed between the topics, whether the number of articles at 70 threshold was above 7 for all topics, the presence (or absence) of exclusive words, and the strength of the scores assigned to the articles most associated to each topic.

The author also explored the results of the drill-down function of the J-tool when a single topic had 20 or more articles associated with it. A drill down is when the J-tool uses the articles associated with one topic as the input for a new topic model. The same fit parameters were used to determine if the drill-down fit well enough to include in the topic model. What this means in practical terms is that the one topic can be divided into two sub-topics.

The articles within a topic are clustered together by Jtool because they are calculated to be related to each other in some way. To give that relationship meaning, a theme name may be interpreted and applied by the analyst based on the model results, which include the words most exclusive to the topic, the most common words, the words that tend to appear together, and the titles of the articles most associated to the topic in order of strength.

A close examination of the J-tool results allows a researcher to describe the underlying theme of each topic. In this study, the descriptions of the different themes found in the 44 selected articles enabled the identification of the distinctive features of the transnational entrepreneurship literature.

\section{Findings}

A topic model of two topics was determined to be the best fit for the corpus, followed by a drill-down of Topic 2 into two subtopics. Thus, three topics (Topic 1, Subtopic 1, and Subtopic 2) were analyzed, as illustrated in Figure 1, which shows the structure of the topics (and subtopics) in addition to the number of articles and the three most common words in each topic.

Theme names were determined subjectively after an examination of the J-tool output for each of the three topics. The resulting theme names assigned to the topics are "Enter Foreign Markets", "Leverage Ethnic Enclave", and "Bridge the Divide". 


\section{Transnational Entrepreneurship: Distinctive Features and a New Definition}

\section{Eduardo Bailetti}

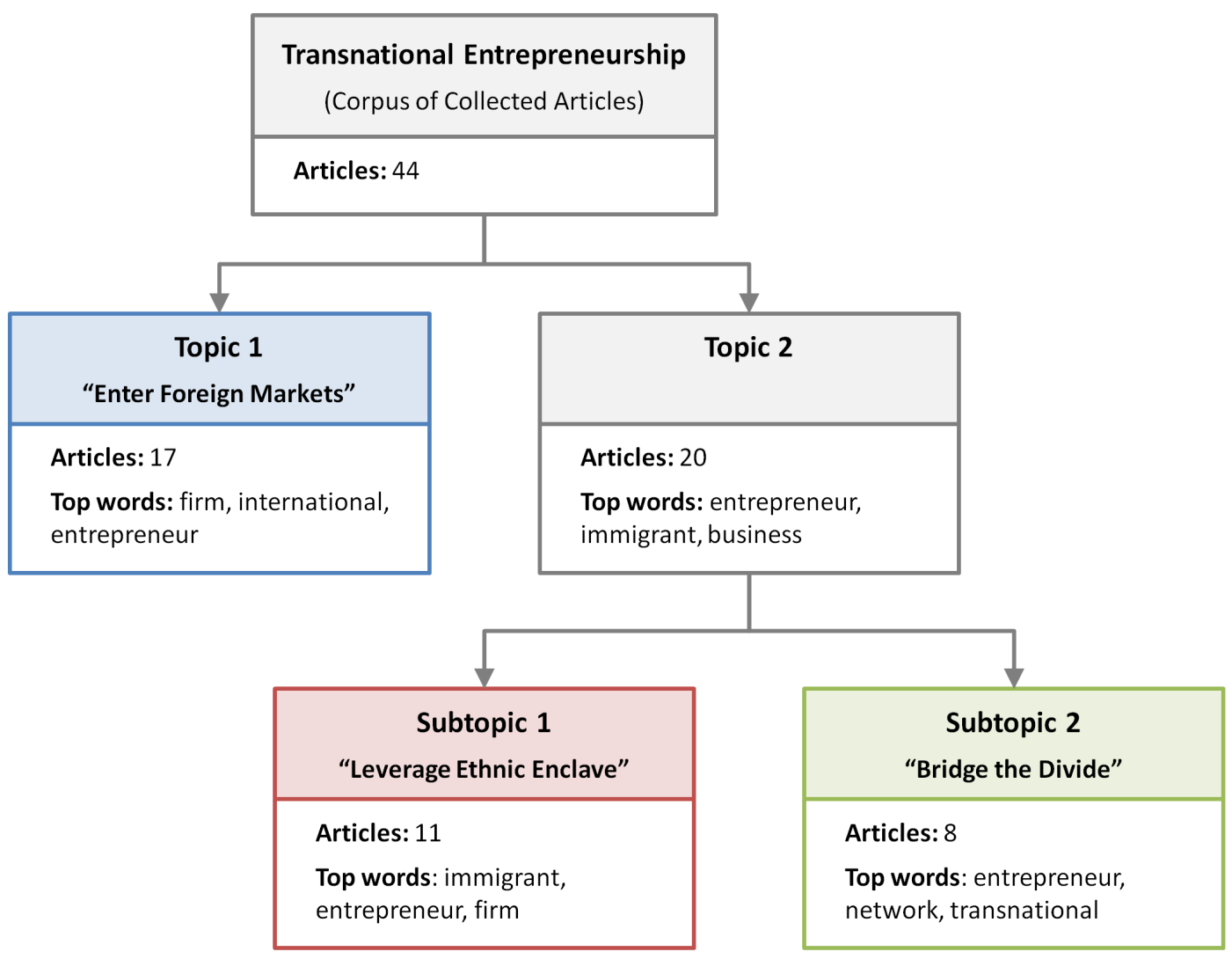

Figure 1. Topics and subtopics of the transnational entrepreneurship topic model

Topic 1 focuses on describing the characteristics of the new company that is seeking to grow in foreign markets. The topic modelling clustered articles that discussed the internationalization of companies mostly in the context of exporting. This did not appear to contribute to the distinctiveness of transnational entrepreneurship as other fields cover this type of internationalization pathway. The name for Topic 1 was concluded to be "Enter Foreign Markets".

The theme of Subtopic 1 was described as "Leverage Ethnic Enclave". The focus of the topic was on the actions of a new company that contribute to performance-based outcomes of growth, survival, and economic development. The new company leverages the networks within the ethnic enclaves of different regions to establish a working relationship with actors within or associated with the enclave. The networking activities of the ethnic enclave are determined by its entrepreneurial orientation. The unique characteristic of Subtopic 1 was noted as the new company's action of leveraging the power of an ethnic enclave to access additional resources, information, and social capital.
The theme of Subtopic 2 was described as "Bridge the Divide", and it depicts the new company internationalizing through business relationships with actors in two distinct economic regions. The new company bridges the divide between the two geographically separated regions and balances the networks it has on both sides. Although the new company's pursuit of internationalization is common between Subtopic 2 and Topic 1, it is the bridging of the divide and balancing of networks between the different regions that are the unique characteristics of Subtopic 2.

\section{Distinctiveness}

The results indicate that there are two key features that distinguish transnational entrepreneurship from other research fields: a cross-border investment and institutional distance. This assertion is based on the findings from Table 1 and the topic modelling. By forming relationships in two or more countries, a company can access a greater variety of opportunities and information on assets, customers, suppliers, and partners than by operating in only one country. 


\section{Transnational Entrepreneurship: Distinctive Features and a New Definition}

\section{Eduardo Bailetti}

To form relationships with actors in foreign countries, the company makes a cross-border investment (e.g., foreign direct investment, portfolio equity securities, debt securities, and loans). Each investment has a logic that is dependent on the investment instrument used and the institutional distance between the distinctive settings. For instance, foreign direct investment is more sensitive to information flows than equity and debt securities due to ownership implications requiring deep market knowledge and more frequent interactions (Daude \& Fratzscher, 2008). Institutional distance has three dimensions: normative, cognitive, and regulatory (Eden \& Miller, 2004), and it is deemed critical to the logic used by companies that span national boundaries (Bae \& Solomom, 2010; Krammer, 2018). Institutional distance has been identified in the transnational entrepreneurship literature as the "cultural, economic, and institutional gap" (Li et al., 2017) and the "geographic, cultural, and psychological distance" (Terjesen \& Elam, 2009), but its strategic significance had not yet been identified to the best of the researcher's knowledge. This article uses institutional distance as a catch-all for the differences that exist between two countries that would affect business.

The formal logic used to make the cross-border investment follows an accountable process that influences the balance between investing in the country of resid- ence and investing in foreign countries. For example, a company that wishes to respond to local adjustments in every country in which it operates will make different cross-border investments than a company that wishes to maximize production efficiency (Edwards et al., 2014).

As illustrated in the topic modelling analysis, the literature connected with Subtopic 2 highlights the need for a company to bridge the divide that exists between itself and foreign actors. When a company makes a cross-border investment, it forms relationships with one or more actors in a foreign country. This foreign actor is within a setting that is part of a foreign country. Similarly, the company that makes the cross-border investment is within a setting that is part of the country of residence. To benefit from a cross-border investment, the company needs to exploit the differences that exist between the company's setting and the foreign actor's setting.

Figure 2 illustrates the aspects that distinguish transnational entrepreneurship from other fields: specifically, the cross-border investment logic and the institutional distance between two countries (setting A and setting B). The figure shows that a company will operate in two countries when it expects the return on its cross-border investment to be higher than the expected return from operating in one country (i.e., Scenario $1<$ Scenario 2 ).

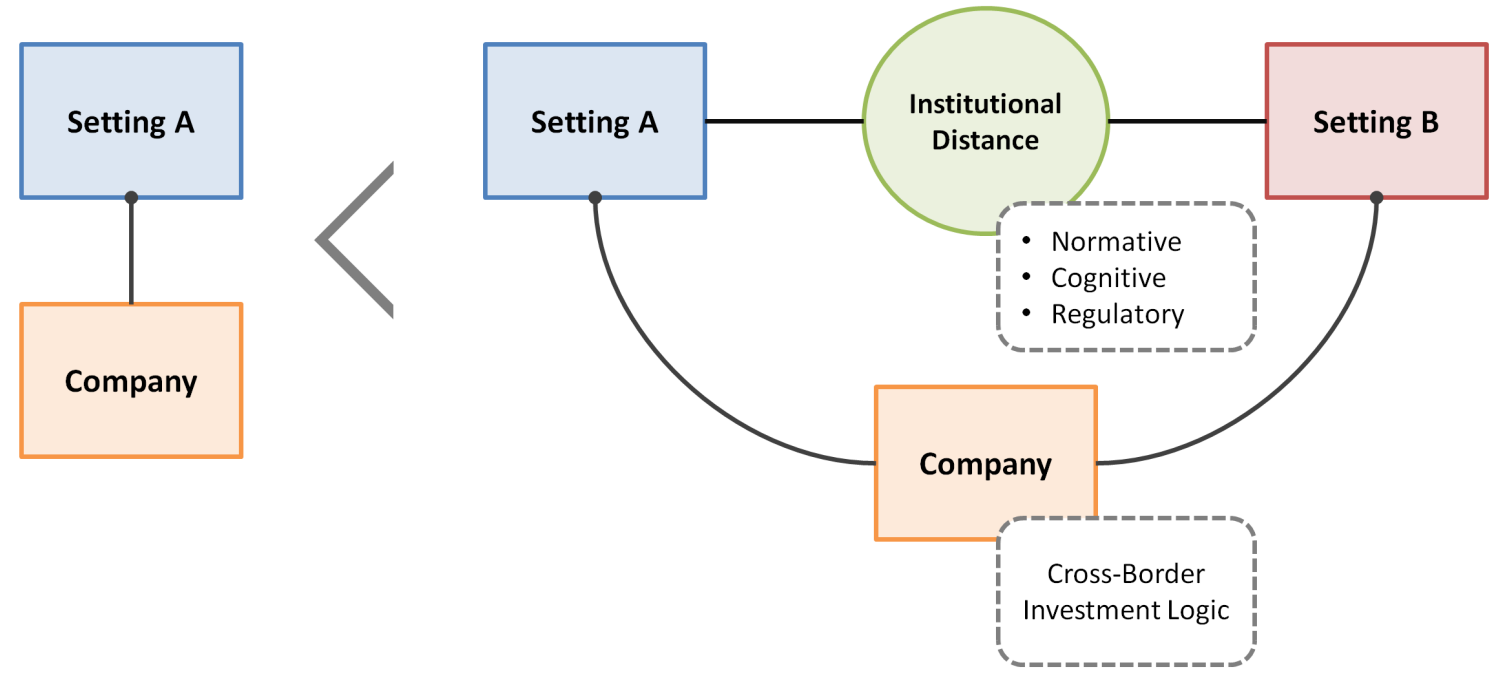

Scenario 1

Operating in

one country
Scenario 2

Operating in

two countries

Figure 2. Two scenarios illustrating the distinctive aspects of transnational entrepreneurship 


\section{Transnational Entrepreneurship: Distinctive Features and a New Definition}

\section{Eduardo Bailetti}

\section{A New Definition of Transnational Entrepreneurship}

Based on the results of the analysis described above, this study proposes that transnational entrepreneurship should be defined as:

a cross-border investment to acquire, combine, and recombine specialized individuals and heterogeneous assets to create and capture value for the company under conditions of institutional distance and uncertainty.

The proposed definition of transnational entrepreneurship is based on the four elements in the definition of technology entrepreneurship provided by Bailetti (2012):

1. Ultimate outcomes: Value creation and capture are identified as the two outcomes of transnational entrepreneurship.

2. Target of the ultimate outcomes: The company is identified as the target organization for which transnational entrepreneurship creates and captures value.

\section{Mechanism used to deliver the ultimate outcomes:} The cross-border investment in a project is the mechanism that mobilizes resources used to create and capture value across two or more countries. A project is the deployment of a stock of resources (i.e., specialized individuals and heterogeneous assets) committed to delivering the two ultimate outcome types for a period.

\section{Interdependence of this mechanism with countries} involved: The resources involved in a project influence, and are influenced by, changes in the countries which they are assembled from.

When compared to the definitions identified in Table 1, the proposed transnational entrepreneurship definition:

1. Emphasizes that transnational entrepreneurship is about creating and capturing value for the company. Value capture is evidenced through the growth metrics of the company, not through describing the entrepreneur.

2. Specifies that the cross-border investment acts as the mechanism to assemble and deploy specialists and assets. Without an investment in the foreign country, the assembly of specialists and assets would not be possible, and the company could not become embedded in that country.

3. Identifies institutional distance as a key condition in which the cross-border investment logic is made. The greater the distance, the greater the opportunity (Krammer, 2018).

4. Transcends the limiting notion that transnational entrepreneurship is about the ethnicity or immigration status of the founding entrepreneur. The foreign experience of the founder or the team employed with the company will influence the company's ability to engage actors in foreign settings, but this is not viewed as a defining characteristic of transnational entrepreneurship.

5. Highlights that specialists and assets, and the advantages available through the combinations of them, are intricately linked to changes in the countries from which they are accessed. If the company is invested in a country and the structure of that country changes due to socio-political or economic factors, then the company will be affected because of its interconnectedness.

6. Allows for more rigorous and practical assessment. The component parts of the definition - i) value creation and capture as the ultimate outcomes, ii) the company as the target, iii) the cross-border investment as the mechanism, iv) the interdependencies between company and state, and v) the institutional distance between settings - can each be explored independently or in conjunction.

\section{Managerial Implications for New Companies}

There are at least four implications for managers of new companies. First, the greater the institutional distance, the greater the opportunity. New company managers can view institutional distance as a positive rather than a negative when it comes to the exploration and discovery of new opportunities. A new company wishing to increase expected outcomes by embedding in a foreign country should look to countries with high degrees of institutional distance relative to their current country of operation. There will be exceptions. For example, a democratic company embedding in a communist country will have a tough time extracting the value captured in that country to invest somewhere else, so managers must use judgement to find the best case. 


\section{Transnational Entrepreneurship: Distinctive Features and a New Definition}

\section{Eduardo Bailetti}

The second managerial implication is that managers must balance the investment in the country of residence and foreign countries. Equally, managers must use a balanced strategy when structuring their crossborder investments. Each setting invested in by the transnational company is important and cannot be traded-off because the company needs both to achieve its comparative advantage. Investments within each setting must also follow a balancing strategy between efficiency and adjustment because it is the only way a young company can survive. For instance, if a new company invests in a country to access customers, its offer can have core and customizable elements to meet demands for efficiency and adjustment. Similarly, if the investment is to access specialized individuals, managers can find a balance locally with workflow processes and technology that are standardized for efficiency and use motivation and reward mechanisms adjusted to the local cultural context.

Greater understanding of the reasons why a new company becomes a transnational is the third managerial implication. A new growth-oriented company must gain from expanding its operations from a single country to two or more countries. Managers pursuing transnational entrepreneurship should seriously consider establishing operations in a second country, which will provide access to people and assets that will increase the new company's capacity to create and capture value.

The fourth managerial implication is that new companies should pursue transnational entrepreneurship regardless of ethnicity, migrancy, or immigration. The core of transnational entrepreneurship is separate from the ethnicity, migrancy, or immigration status of the company's founders and team. For example, managers interested in engaging in transnational entrepreneurship may or may not engage with an ethnic enclave of the foreign country in which they intend to establish operations.

\section{Conclusion}

This article contributes a definition of transnational entrepreneurship where the company is the focal actor, a cross-border investment in specialized individuals and heterogeneous assets is the mechanism the company uses to create and capture value, and the investment is made under conditions of institutional distance between distinct settings.
The author asserts that two features distinguish transnational entrepreneurship from other forms of entrepreneurship: cross-border investment logic and institutional distance. A cross-border investment should be made to capture more value for the company than if it were to operate only in the country of residence.

The proposed new definition asserts that the investment is interdependent with changes in the settings in which the company is embedded. The company's value capture abilities are subject to the risk and reward of structural changes in the foreign setting being invested in. This implies exposure to, and interest in, changes in the foreign country's setting due to resulting effects on the company's profitability.

Ethnicity has been dropped from the definition because it is not core to the observed distinctiveness of the field. Instead, this definition allows the field to move forward with a focus on the value creation and capture activities of the company as the definition is independent of the stage of the company, applying equally well to a new company and a mature company, and it is free of the limiting component of the ethnicity of the founder. This makes the definition highly relevant for startups given that most existing definitions seem to reflect the context of larger and more mature firms (Tanev, 2017).

The article identifies the practical value of identifying the distinctiveness of transnational entrepreneurship from the managerial perspective. It also compares the new definition with previous definitions of transnational entrepreneurship. The value of the component parts of the definition provides a framework that future researchers can use to conduct a deeper examination of the field.

The new definition allows researchers to connect transnational entrepreneurship to other streams of research, particularly entrepreneurship, international business, institutional theory, knowledge spillover, glocalization, and regional economic development. The assertion for regional economic development is that, if an investment is being made by the company into a new country, the investment will be so that new value can be created in that market and the company can capture a portion of it. The value that is not captured by the company will be captured by local suppliers, partners, and customers, thus contributing to the economic development of the region. 


\section{Transnational Entrepreneurship: Distinctive Features and a New Definition}

\section{Eduardo Bailetti}

The author hopes that this article and the new definition of transnational entrepreneurship inspires researchers from an array of fields to contribute to the understanding of transnational entrepreneurship and to connect it to other streams of research. Further exploration of the distinctive characteristics of the crossborder investment, the investment logic, and the institutional distance would be valuable contributions to further understanding of transnational entrepreneurship. The relationship between the company, the state, and the changing environment in which the company is embedded is also an interesting direction that could be fruitful.

\section{References}

Australian Business Deans Council. 2018. Master Journal List. Australian Business Deans Council. Accessed April 20, 2018: http://www.abdc.edu.au/master-journal-list.php

Bae, J. H., \& Salomon, R. 2010. Institutional Distance in International Business Research. In D. Timothy, P. Torben, \& T. Laszlo (Eds.), The Past, Present and Future of International Business \& Management: 327-349. Bingley, UK: Emerald Group Publishing Limited.

Bailetti, T. 2012. Technology Entrepreneurship: Overview, Definition, and Distinctive Aspects. Technology Innovation Management Review, 2(2): 5-12.

http://doi.org/10.22215/timreview/520

Blei, D. M. 2012. Probabilistic Topic Models. Communications of the ACM, 55(4): 77-84.

http://dx.doi.org/10.1145/2133806.2133826

Blei, D. M., \& Lafferty, J. D. 2009. Topic Models. In A. Srivastava \& M. Sahami (Eds.), Text Mining: Theory and Applications: 101-124. New York: Taylor \& Francis.

Blei, D. M., Ng, A. Y., \& Jordan, M. I. 2003. Latent Dirichlet Allocation. Journal of Machine Learning Research, 3(1): 993-1022.

Brzozowski, J., Cucculelli, M., \& Surdej, A. 2014. Transnational Ties and Performance of Immigrant Entrepreneurs: The Role of HomeCountry Conditions. Entrepreneurship \& Regional Development, 26(7-8): 546-573.

https://doi.org/10.1080/08985626.2014.959068

Brzozowski, J., Cucculelli, M., \& Surdej, A. 2017. The Determinants of Transnational Entrepreneurship and Transnational Ties' Dynamics Among Immigrant Entrepreneurs in ICT Sector in Italy. International Migration, 55(3): 105-125.

https://doi.org/10.1111/imig.12335

Chen, W., \& Tan, J. 2009. Understanding Transnational Entrepreneurship Through a Network Lens: Theoretical and Methodological Considerations. Entrepreneurship Theory and Practice, 33(5): 1079-1091.

https://doi.org/10.1111/j.1540-6520.2009.00335.x

Daude, C., \& Fratzscher, M. 2008. The Pecking Order of Cross-Border Investment. Journal of International Economics, 74(1): 94-119.

\section{About the Author}

Eduardo Bailetti is a graduate student undertaking a master's degree in Entrepreneurship from the Technology Innovation Management program at Carleton University in Ottawa, Canada. He holds a BA in Economics, at Carleton University and has experience in industry as a manager and a venture founder. His research interests focus on combining and applying theory and practice to grow new ventures early, rapidly, and securely.

Drori, I., Honig, B., \& Wright, M. 2009. Transnational Entrepreneurship: An Emergent Field of Study. Entrepreneurship Theory and Practice, 33(5): 1001-1022.

Eden, L., \& Miller, S. R. 2004. Distance Matters: Liability of Foreignness, Institutional Distance and Ownership Strategy. In M. A. Hitt \& J. L. C. Cheng (Eds.), Theories of the Multinational Enterprise: Diversity, Complexity and Relevance: 187-221. Bingley, UK: Emerald Group Publishing Limited.

Edwards, J., Ketchen, D., Short, J., \& Try, D. 2014. Mastering Strategic Management. Victoria, BC: BC Campus.

http://doer.col.org/handle/123456789/5642

Foss, N. J., Klein, P. G., \& Bylund, P. L. 2011. Entrepreneurship and the Economics of the Firm. In D. Hjorth \& E. Elgar (Ed.), Handbook of Organisational Entrepreneurship, Forthcoming. https://ssrn.com/abstract=1747710

Klein, P. G. 2016. Why Entrepreneurs Need Firms, and the Theory of the Firm Needs Entrepreneurship Theory. Revista de Administração, 51(3): 323-326. https://doi.org/10.1016/j.rausp.2016.06.007

Krammer, S. M. S. 2018. A Double-Edged Sword? The Antipodal Effects of Institutional Distance on Partner Selection in CrossBorder Alliances. Journal of World Business, 53(6): 930-943. http://doi.org/10.1016/j.jwb.2018.08.001

Lin, X. 2010. The Diaspora Solution to Innovation Capacity Development: Immigrant Entrepreneurs in the Contemporary World. Thunderbird International Business Review, 52(2): 123-136.

McCallum, A. K. 2002. MALLET: A Machine Learning for Language Toolkit. http://mallet.cs.umass.edu

Patel, P. C., \& Conklin, B. 2009. The Balancing Act: The Role of Transnational Habitus and Social Networks in Balancing Transnational Entrepreneurial Activities. Entrepreneurship Theory and Practice, 33(5): 1045-1078.

Patel, P. C., \& Terjesen, S. 2011. Complementary Effects of Network Range and Tie Strength in Enhancing Transnational Venture Performance. Strategic Entrepreneurship Journal, 5(1): 58-80.

Poblete, C. 2018. Shaping the Castle According to the Rocks in the Path? Perceived Discrimination, Social Differences, and Subjective Wellbeing as Determinants of Firm Type Among Immigrant Entrepreneurs. Journal of International Entrepreneurship, 16(2): 276-300. 


\section{Transnational Entrepreneurship: Distinctive Features and a New Definition}

\section{Eduardo Bailetti}

Prashantham, S., Eranova, M., \& Couper, C. 2018. Globalization, Entrepreneurship and Paradox Thinking. Asia Pacific Journal of Management, 35(1): 1-9.

https://doi.org/10.1007/s10490-017-9537-9

Santamaria-Alvarez, S. M., Muñoz-Castro, D. C., Sarmiento-González, M. A., \& Marín-Zapata, S. I. 2018. Fragmented Networks and Transnational Entrepreneurship: Building Strategies to Prosper in Challenging Surroundings. Journal of International Entrepreneurship, 16(2): 244-275.

http://doi.org/10.1007/s10843-017-0215-2
Sequeira, J. M., Carr, J. C., \& Rasheed, A. A. 2009. Transnational Entrepreneurship: Determinants of New Company Type and Owner Attributions of Success. Entrepreneurship Theory and Practice, 33(5): 1023-1044. https://doi.org/10.1111/j.1540-6520.2009.00333.x

Tanev, S. 2017. Is There a Lean Future for Global Startups? Technology Innovation Management Review, 7(5): 6-15. http://doi.org/10.22215/timreview/1072

\section{Appendix A. Corpus of articles related to transnational entrepreneurship used for analysis in this study}

Bai, W., Johanson, M., \& Martín, O. M. 2017. Knowledge and Internationalization of Returnee Entrepreneurial Firms. International Business Review, 26(4): 652-665. https://doi.org/10.1016/j.ibusrev.2016.12.006

Bai, W., \& Johanson, M. 2018. International Opportunity Networks. Industrial Marketing Management, 70: 167-179. https://doi.org/10.1016/j.indmarman.2017.07.004

Bai, W., Holmström-Lind, C., \& Johanson, M. 2018. Leveraging Networks, Capabilities and Opportunities for International Success: A Study on Returnee Entrepreneurial Ventures. Scandinavian Journal of Management, 34(1): 51-62. https://doi.org/10.1016/j.scaman.2017.12.001

Bell, V. A., \& Cooper, S. Y. 2018. Institutional Knowledge: Acquisition, Assimilation and Exploitation in Internationalisation. International Marketing Review, 35(3): 475-497. https://doi.org/10.1108/IMR-05-2016-0111

Binz, C., \& Truffer, B. 2017. Global Innovation Systems-A Conceptual Framework for Innovation Dynamics in Transnational Contexts. Research Policy, 46(7): 1284-1298. https://doi.org/10.1016/j.respol.2017.05.012

Brzozowski, J., Cucculelli, M., \& Surdej, A. 2014. Transnational Ties and Performance of Immigrant Entrepreneurs: The Role of HomeCountry Conditions. Entrepreneurship \& Regional Development, 26(7-8): 546-573.

https://doi.org/10.1080/08985626.2014.959068

Brzozowski, J., Cucculelli, M., \& Surdej, A. 2017. The Determinants of Transnational Entrepreneurship and Transnational Ties' Dynamics Among Immigrant Entrepreneurs in ICT Sector in Italy. International Migration, 55(3): 105-125. https://doi.org/10.1111/imig.12335

Chen, W., \& Tan, J. 2009. Understanding Transnational Entrepreneurship through a Network Lens: Theoretical and Methodological Considerations. Entrepreneurship Theory and Practice, 33(5): 1079-1091.

https://doi.org/10.1111/j.1540-6520.2009.00335.x

Chung, H. F., \& Tung, R. L. 2013. Immigrant Social Networks and Foreign Entry: Australia and New Zealand Firms in the European Union and Greater China. International Business Review, 22(1): $18-31$.

http://doi.org/10.1016/j.ibusrev.2012.01.005

Collins, J., \& Low, A. 2010. Asian Female Immigrant Entrepreneurs in Small and Medium-Sized Businesses in Australia. Entrepreneurship and Regional Development, 22(1): 97-111. https://doi.org/10.1080/08985620903220553
Dimitratos, P., Buck, T., Fletcher, M., \& Li, N. 2016. The Motivation of International Entrepreneurship: The Case of Chinese Transnational Entrepreneurs. International Business Review, 25(5): 1103-1113. http://dx.doi.org/10.1016/j.ibusrev.2016.01.012

Dimitratos, P., Petrou, A., Plakoyiannaki, E., \& Johnson, J. E. 2011. Strategic Decision-Making Processes in Internationalization: Does National Culture of the Focal Firm Matter? Journal of World Business, 46(2): 194-204.

https://doi.org/10.1016/j.jwb.2010.05.002

Dimitratos, P., Voudouris, I., Plakoyiannaki, E., \& Nakos, G. 2012. International Entrepreneurial Culture-Toward a Comprehensive Opportunity-Based Operationalization of International Entrepreneurship. International Business Review, 21(4): 708-721. https://doi.org/10.1016/j.ibusrev.2011.08.001

Drori, I., Honig, B., \& Wright, M. 2009. Transnational Entrepreneurship: An Emergent Field of Study. Entrepreneurship Theory and Practice, 33(5): 1001-1022. https://doi.org/10.1111/j.1540-6520.2009.00332.x

Gabrielsson, P., \& Gabrielsson, M. 2013. A Dynamic Model of Growth Phases and Survival in International Business-To-Business New Ventures: The Moderating Effect of Decision-Making Logic. Industrial Marketing Management, 42(8): 1357-1373. https://doi.org/10.1016/j.indmarman.2013.07.011

Gabrielsson, M., Gabrielsson, P., \& Dimitratos, P. 2014. International Entrepreneurial Culture and Growth of International New Ventures. Management International Review, 54(4): 445-471. https://doi.org/10.1007/s11575-014-0213-8

Hernandez, E. 2014. Finding a Home away from Home: Effects of Immigrants on Firms' Foreign Location Choice and Performance. Administrative Science Quarterly, 59(1): 73-108. https://doi.org/10.1177/0001839214523428

Hewerdine, L. J., Rumyantseva, M., \& Welch, C. 2014. Resource Scavenging: Another Dimension of the Internationalisation Pattern of High-Tech SMEs. International Marketing Review, 31(3): 237-258. https://doi.org/10.1108/IMR-11-2012-0194

Ji, J., \& Dimitratos, P. 2013. Confucian Dynamism and Dunning's Framework: Direct and Moderation Associations in Internationalized Chinese Private Firms. Journal of Business Research, 66(12): 2375-2382. https://doi.org/10.1016/j.jbusres.2013.05.023 


\section{Transnational Entrepreneurship: Distinctive Features and a New Definition}

\section{Eduardo Bailetti}

Jiang, G., Kotabe, M., Hamilton III, R. D., \& Smith, S. W. 2016. Early Internationalization and the Role of Immigration in New Venture Survival. International Business Review, 25(6): 1285-1296. https://doi.org/10.1016/j.ibusrev.2016.04.001

Jones, M. V., Coviello, N., \& Tang, Y. K. 2011. International Entrepreneurship Research (1989-2009): A Domain Ontology and Thematic Analysis. Journal of Business Venturing, 26(6): 632-659. https://dx.doi.org/10.1016/j.jbusvent.2011.04.001

Kariv, D., Menzies, T. V., Brenner, G. A., \& Filion, L. J. 2009. Transnational Networking and Business Performance: Ethnic Entrepreneurs in Canada. Entrepreneurship and Regional Development, 21(3): 239-264.

https://doi.org/10.1080/08985620802261641

Kenney, M., Breznitz, D., \& Murphree, M. 2013. Coming Back Home after the Sun Rises: Returnee Entrepreneurs and Growth of High Tech Industries. Research Policy, 42(2): 391-407. https://doi.org/10.1016/j.respol.2012.08.001

Kulchina, E. 2016. A Path to Value Creation for Foreign Entrepreneurs. Strategic Management Journal, 37(7): 1240-1262. https://doi.org/10.1002/smj.2403

Li, C., Isidor, R., Dau, L. A., \& Kabst, R. 2018. The More the Merrier? Immigrant Share and Entrepreneurial Activities. Entrepreneurship Theory and Practice, 42(5): 698-733. https://doi.org/10.1111/etap.12277

Monaghan, S., \& Tippmann, E., 2018. Becoming a Multinational Enterprise: Using Industry Recipes to Achieve Rapid Multinationalization. Journal of International Business Studies, 49(4): 473-495.

https://doi.org/10.1057/s41267-017-0137-1

Ndofor, H.A., \& Priem, R.L. 2011. Immigrant Entrepreneurs, the Ethnic Enclave Strategy, and Venture Performance. Journal of Management, 37(3): 790-818.

https://doi.org/10.1177/0149206309345020

Neville, F., Orser, B., Riding, A., \& Jung, O. 2014. Do Young Firms Owned by Recent Immigrants Outperform other Young Firms? Journal of Business Venturing, 29(1): 55-71. https://doi.org/10.1016/j.jbusvent.2012.10.005

Patel, P. C., \& Conklin, B. 2009. The Balancing Act: The Role of Transnational Habitus and Social Networks in Balancing Transnational Entrepreneurial Activities. Entrepreneurship Theory and Practice, 33(5): 1045-1078. https://doi.org/10.1111/j.1540-6520.2009.00334.x

Patel, P. C., \& Terjesen, S. 2011. Complementary Effects of Network Range and Tie Strength in Enhancing Transnational Venture Performance. Strategic Entrepreneurship Journal, 5(1): 58-80. https://doi.org/10.1002/sej.107

Prashantham, S., Dhanaraj, C., \& Kumar, K. 2015. Ties That Bind: Ethnic Ties and New Venture Internationalization. Long Range Planning, 48(5): 317-333. https://doi.org/10.1016/j.lrp.2015.02.005

Prashantham, S., Eranova, M., \& Couper, C. 2018. Globalization, Entrepreneurship and Paradox Thinking. Asia Pacific Journal of Management, 35(1): 1-9.

https://doi.org/10.1007/s10490-017-9537-9

Pruthi, S., 2014. Social Ties and Venture Creation by Returnee Entrepreneurs. International Business Review, 23(6): 1139-1152. https://doi.org/10.1016/j.ibusrev.2014.03.012
Riddle, L., \& Brinkerhoff, J. 2011. Diaspora Entrepreneurs as Institutional Change Agents: The Case of Thamel.com. International Business Review, 20(6): 670-680. https://doi.org/10.1016/j.ibusrev.2011.02.013

Riddle, L., Hrivnak, G. A., \& Nielsen, T. M. 2010. Transnational Diaspora Entrepreneurship in Emerging Markets: Bridging Institutional Divides. Journal of International Management, 16(4): 398-411.

https://doi.org/10.1016/j.intman.2010.09.009

Sequeira, J. M., Carr, J. C., \& Rasheed, A. A. 2009. Transnational Entrepreneurship: Determinants of Firm Type and Owner Attributions of Success. Entrepreneurship Theory and Practice, 33(5): 1023-1044.

https://doi.org/10.1111/j.1540-6520.2009.00333.x

Sommer, E., \& Gamper, M. 2018. Transnational Entrepreneurial Activities: A Qualitative Network Study of Self-Employed Migrants from the former Soviet Union in Germany. Social Networks, 53: 136-147.

https://doi.org/10.1016/j.socnet.2017.04.007

Stoyanov, S., Woodward, R., \& Stoyanova, V. 2017. The Embedding of Transnational Entrepreneurs in Diaspora Networks: Leveraging the Assets of Foreignness. Management International Review: 1-32. https://doi.org/10.1007/s11575-017-0336-9

Terjesen, S., \& Elam, A. 2009. Transnational Entrepreneurs' Venture Internationalization Strategies: A Practice Theory Approach. Entrepreneurship Theory and Practice, 33(5): 1093-1120. https://doi.org/10.1111/j.1540-6520.2009.00336.x

Urbano, D., Toledano, N., \& Ribeiro-Soriano, D. 2011. Socio-Cultural Factors and Transnational Entrepreneurship: A Multiple Case Study of Spain. International Small Business Journal, 29(2): 119-134. https://doi.org/10.1177/0266242610391934

Wang, C. L., \& Altinay, L. 2012. Social Embeddedness, Entrepreneurial Orientation and Firm Growth in Ethnic Minority Small Businesses in the UK. International Small Business Journal, 30(1): 3-23. https://doi.org/10.1177/0266242610366060

Wang, Q., \& Liu, C. Y. 2015. Transnational Activities of ImmigrantOwned Firms and Their Performances in the USA. Small Business Economics, 44(2): 345-359. https://doi.org/10.1007/s11187-014-9595-Z

Zhou, L. 2007. The Effects of Entrepreneurial Proclivity and Foreign Market Knowledge on Early Internationalization. Journal of World Business, 42(3): 281-293. https://doi.org/10.1016/j.jwb.2007.04.009

Zolin, R., \& Schlosser, F. 2013. Characteristics of Immigrant Entrepreneurs and their Involvement in International New Ventures. Thunderbird International Business Review, 55(3): 271-284. https://doi.org/10.1002/tie.21543

Citation: Bailetti, E. 2018. Transnational Entrepreneurship: Distinctive Features and a New (cc) BY Definition. Technology Innovation Management Review, 8(9): 28-38. http://doi.org/10.22215/timreview/1184

Keywords: transnational, cross-border, entrepreneurship, definition, features, topic modelling 


\section{Academic Affiliations and Funding Acknowledgements}

Canadà
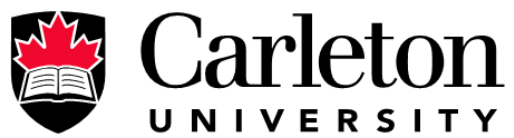

U N I V E R S I T Y

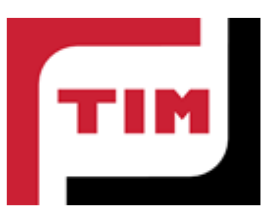

The Federal Economic Development Agency for Southern Ontario (FedDev Ontario; feddevontario.gc.ca) is part of the Innovation, Science and Economic Development portfolio and one of six regional development agencies, each of which helps to address key economic challenges by providing regionallytailored programs, services, knowledge and expertise.

- The TIM Review receives partial funding from FedDev Ontario's Investing in Regional Diversification initiative.

Technology Innovation Management (TIM; timprogram.ca) is an international master's level program at Carleton University in Ottawa, Canada. It leads to a Master of Applied Science (M.A.Sc.) degree, a Master of Engineering (M.Eng.) degree, or a Master of Entrepreneurship (M.Ent.) degree. The objective of this program is to train aspiring entrepreneurs on creating wealth at the early stages of company or opportunity lifecycles.

- The TIM Review is published in association with and receives partial funding from the TIM program. 